\title{
Single-use Plastic Ban and its Public Health Impacts: A Narrative Review
}

\author{
Nilofur Banu
}

\begin{abstract}
Introduction: Plastic initially played a major role in conserving natural source from extension but later plastic pollution become a growing concern for nearly a decade, especially single use plastics. Various effects were taken to tackle the situation in different part of the world, among those were imposing ban, levy and policies. Very few studies have analyzed the policy and legislative that deal with plastic pollution generated by single-use plastics (SUP). This paper reviews various policies and strategies to reduce SUP and its public health impact.

Materials and methods: To address the issues associated with SUP pollution, a literature review was done to assess current ban and policies. Search engine such as PubMed and Google Scholar were used. Apart from these search engine certain standardized web portal like WHO, UN reports and press and reports were included in the studies to know about the current policies, ban and legislations were included in the study. Results: effectiveness of various bans and levies were analyzed, various strategies which made it effective were found and impact of these ban and levies on public health were also identified of which high levy, tough enforcement and personal behavior has shown impact in reducing SUP whereas lack of continuous vigilance, self regulation by industries and illegally SUP production had led to failure to create impact by various bans and levy

Conclusion: Based on this study, it is evident that more tougher enforcement, vigilance, and self-regulation along with motivations of the public may help to curb SUP pollution.

Keywords: Single-use plastic, Single-use plastic legislation, Single-use plastic pollution.

Annals of SBV (2019): 10.5005/jp-journals-10085-8102
\end{abstract}

\section{INTRODUCTION}

The word plastic has derived from the Greek word plastikos, which means capable of being molded or shaped into any form. Plastics had evolved from natural plastic materials like chewing gum to chemically modified natural substances like natural rubber, collagen, nitrocellulose, etc. and finally as a complete synthetic molecule. ${ }^{1}$

During the industrial revolution in the nineteenth century, many materials were discovered and reported and one such material was Parkesine which is considered as the first man-made plastic; it was patented by Alexander Parkes. ${ }^{2}$

In 1907, the first fully synthetic plastic, i.e., contains no molecule found in nature, was invented by Leo Baekeland and named it as Bakelite; it was the outcome of his search for a material which would substitute the natural insulator shellac. The newly found Bakelite had a multiple purposes like heat resistant, durable and molded into any shape apart from being a good insulator and was marketed as "the material of a thousand uses." ${ }^{3}$

There are two main categories of plastic, thermoplastics and thermosets, based on their setting nature when heated and the chemical composition. Thermoplastics are the most common type; they belong to a plastic family that can be melted and hardened when heated and cooled, respectively. These characteristics are reversible as well and can be repeatedly reshaped. They include substances like polyethylene terephtalate (PET), low-density polyethylene (LDPE), high-density polyethylene (HDPE), polypropylene (PE), polystyrene (PS), polyvinyl chloride (PVC), expanded polystyrene (EPS), polycarbonate, polypropylene (PP), polyhydroxyalkanoates (PHA), and polylactic acid (PLA). Thermostats are the type of plastics that undergo a chemical change whenever they are heated and thereby creating a three dimensional network. They are different
Department of Community Medicine, Shri Sathya Sai Medical College and Research Institute, Thiruporur, Tamil Nadu, India

Corresponding Author: Nilofur Banu, Department of Community Medicine, Shri Sathya Sai Medical College and Research Institute, Thiruporur, Tamil Nadu, India, Phone: +91 9884607060, e-mail: dr.nilofurbanuu@gmail.com

How to cite this article: Banu N. Single-use Plastic Ban and its Public Health Impacts: A Narrative Review. Ann SBV 2019;8(1):13-18.

Source of support: Nil

Conflict of interest: None

from thermoplastics as they cannot be remelted and reformed. They include substances like polyurethane (PUR), phenolic resins, acrylic resins, ureaformaldehyde (UF), epoxy resins, silicone, vinyl ester, and resin. ${ }^{4}$

\section{Microplastics and Macroplastics}

Plastics are broadly classified into two types of plastics, namely microplastics and macroplastics. Microplastics are the plastics which have thickness of less than $5 \mathrm{~mm}$ and they are of two forms, primary microplastics and secondary microplastics. Primary microplastics are those plastics which are originally produced at the microsize level for applications such as industrial scrubbers or cosmetics, whereas secondary microplastics are fragments that have resulted from the breaking of larger plastic products in a microsize. These microplastics are now widely used in various industries like cosmetic industries which can be hardly identified. Plastics unlike metals do not corrode or rust and are not bordered also, but instead they are photographed which means that they slowly break into small fragments as microplastics. ${ }^{5,6}$ Macroplastics are the plastics which 
have thickness of less than $5 \mathrm{~mm}$, which comprises of larger plastic item and are major cause of littering throughout the world. ${ }^{7}$

\section{Single-use Plastics}

Single-use plastics (SUP) are referred to as the disposable plastics which are mostly used only once before they are recycled or thrown away. ${ }^{4}$ They include plastic bags, food packaging, bottles, straws, microbeads, containers, cups, and cutlery. These SUP are solely to be used only once; they should not be reused again; if reused, again increases the risk of leaching and bacterial growth; SUP are difficult to decontaminate and proper cleaning requires very harmful chemicals. They are mainly made of polyethylene terephthalates which are potential carcinogens when heated. ${ }^{5}$ They belong to recycle code 1 which means they can be recycled but not reused. First they are crushed and then shredded to smaller flakes which are later reprocessed and made into new PET bottles; the recycled fibers are also used as spun into polyester fiber but less than $40 \%$ of SUP waste are recycled and rest are littering the environment, both land and ocean. ${ }^{8}$

\section{Burden of Single-use Plastics}

It is estimated that more than $\mathbf{4 0 0}$ million tons of plastic are produced globally and the studies' findings have indicated that $79 \%$ of the plastic waste ever produced are found in the landfills, dumps and in the environment, about $12 \%$ of plastic waste are incinerated and only $9 \%$ of the plastic waste are recycled. ${ }^{9}$

According to the latest report by the Central Pollution Control Board (CPCB), India generates 15,000 tons of plastic waste every day, of which $43 \%$ are plastic manufactured and contributed from single-use packaging material; most of these waste generated are uncollected and discarded. ${ }^{10}$

Among the other southern Indian states, Tamil Nadu found its way to the top in plastic manufacturing and consumption; nearly 9 lakh tons of plastics and 429 tons of plastic waste are generated from them every day compressing a mix of $80 \%$ of both high-density and low-density polyethylene waste which comprises of carry bags, milk pouches, and packing films. ${ }^{11}$

\section{Impact of Single-use Plastics}

Plastics had various new uses; initially, plastics were used and encouraged because they were found as alternative to natural recourses and thereby conserving those natural resources. ${ }^{3}$

Production of plastic has outnumbered any other material due to the increase in consumption and with a consequence of globalization, the production of durable plastics had shifted toward increase in production of single-use plastics. ${ }^{12}$ According to Geyer et al., the largest sector to use SUP is packaging industries; about $36 \%$ of SUP are used in packaging, $16 \%$ by building and construction, $14 \%$ by textiles, consumer and institutional products use $10 \%$ SUP, $7 \%$ by transport industries, $4 \%$ by electrical and electronic industries and rest by others. ${ }^{9}$

Increase in consumption in turn had led to increased utilization of nonrenewable resources like fossil hydrocarbon. The global estimates suggest that by 2050 , the plastic production may consume $20 \%$ of total world's oil consumption. It has not just stopped in depleting the valuable recourse but has gone further by causing ill effects to humans as well. The ubiquitous use of plastics and daily exposure have facilitated continuous contact of plastic and its ingredients to human body, and studies have suggested the presence of these ingredients in the human body which has reflected the constant exposure as well as its metabolism and excretion of some harmful product of plastics. ${ }^{13}$

By biomonitoring, it is found that multiple sources of plastics had contaminated humans; this approach further showed that various chemicals used in the manufacture of plastics are present in the human population and producing potential adverse effects on health because of these chemicals. ${ }^{14-17}$ Inhalation, ingestion and dermal contact all are considered as important routes by which plastics get exposure in humans and thereby causing harmful effects. ${ }^{18,19}$

Lang et al., in his recent study among the general adult population of the United States, found a significant relationship between the harmful chemicals from SUP and its byproducts causing cardiovascular diseases, abnormalities in liver, type II diabetes and carcinomas in adults who were expose to it, and Stahlhut et al. and Calafat et al. found similar results in their studies..$^{17,20,21}$

However, the problem has not limited itself to just human life; it has also extended its impact to the wildlife and marine species by ingestion and entanglement. It is reported that over 260 species, including mammals, turtles, fish, seabirds and invertebrates, are affected by single-use plastics and causing harmful effects like impaired movement restriction in feeding, reduced reproductive output, multiple wounds, and death. ${ }^{22-27}$

Consequence and the incidence of ingestion are found to be extremely high; about $95 \%$ of fulmars were found to be dead and washed in the North Sea; it is reported that the cause of death was ingestion of plastic bags as an enormous amount of SUP were found in the gut of those birds. ${ }^{28}$

Single-use plastics accounts for widespread contamination of soils with macroplastics or by microplastic fragments and subsequently contaminating municipal solid waste, though sludge into streams, rivers, and ultimately to the sea, as it takes decades to decompose; it is roughly estimated that it may take 1,000 years to decompose. . $^{29-31}$

The extent of these problems is so high such that the deepest point of the sea, 10,898 meters in the Mariana Trench, was observed to be contaminated by $17 \%$ of plastic debris images; it includes mostly entanglement of plastic bags. ${ }^{32}$ Impacts of SUP are well documented in many studies, but very few studies examine policies pertaining to SUP in the environment. The lack of standard global policy aimed to reduce SUP accumulation in the environment was the need for this study.

\section{Methodology and Approach}

Impacts of SUP are well documented in many studies, but very few studies examine policies pertaining to SUP in the environment. The lack of standard global policy aimed to reduce SUP accumulation in the environment was the need for this study. This study reviewed current trends of international strategies and policies for banning or adding levies on SUP.

To address the issues associated with SUP pollution, a literature review was done to assess current ban and policies. Search engines such as Pub med and Google Scholar were used. Apart from these search engines, certain standardized web portals like WHO, UN reports, and press reports were included in the studies to know about the current policies, ban, and legislations. Search terms included "plastic bags," "single-use Plastic," "national policies," "single-use plastic legislation," and "single-use Plastic ban impact." Results that described bans, policies, laws or legislation, single-use 
plastic ban impact related to SUP were included in this review article. Based on these results, different strategies, policies, and areas for future research were identified.

\section{SUP BAN AND ITS IMPACT ACROSS VARIOUS COUNTRIES AND IN INDIA}

Various strategies were implemented wordwide to reduce singleuse plastic. Littering is one of the major issues by SUP and add up to only a small percentage of all litter but the impact of these bags is significantly high; hence, various measures have to be taken, among those measures are ban or levy by the governments of various nations. First country to ban thin plastic bags was Bangladesh and nearly a decade later similar or different ban was imposed on SUP by many developing countries.

In 2001, legislation was passed in Bangladesh to ban the manufacture and sale of SUP; the disastrous floods of 1989 and 1998 were the major drivers for the ban. As SUP were found to exacerbate these major floods due to clogging of underwater drainage by single plastic bags because excessive use and lack of proper disposable system thereby preventing drainage and prolonging the flood; after a period of 3 years, the ban was reversed as there was lack of enforcement and minimum fine was enforced; later regulatory systems were incorporated such as price-based charges which included deposit or refund schemes, and recycling subsidies. ${ }^{33,34}$

In the same year, Ireland became the country to impose tax (levy) on SUP bags and found to be successful in reducing the consumption of SUP bags. Convery et al. analyzed the success story of a plastic bag levy in Ireland; they imposed tax on sale of SUP bags in retail stores with the exception of reuse plastic. It was first aimed to reduce littering in the rural region and later to maintain consumer behavior and increased the levy on SUP-based on per capita increase in consumption. It was possible due to integrated reporting system and collection of tax into already existing value added tax; further, it provided insights, planning, and guidelines for other similar proposals. ${ }^{35}$

In 2002, South Africa enforced the plastic bag ban, but the response was poor. Hasson et al. recommended it is not possible to have one successful policy to reduced SUP, as the demand of SUP was relatively the price of inelastic and not just utilizing price. Therefore, the combination of standards and pricing can successfully curb plastic bag use. ${ }^{36}$

Further, the study of Dikgang et al. supported the finding of Hasson et al. that the initial sharp fall in use of SUP was noticed in South Africa because the plastic bags were charged; later, the consumers got used to paying for bags which slowly rose the demand to a much higher level. ${ }^{37}$

In order to curb single-use plastic waste, various initiatives have been adopted by government of India and one such initiative is the ban on SUP. Plastic manufacture sale and usage rules 1999 (amended in 2003) was implemented to regulate the manufacture, sale and use, and recycling of plastic bags. Further in 2011, the Ministry of Environment and Forests had notified another plastic waste rules for management and handling purpose in supersession of the earlier rules as it is a partial ban. Some of the most noticeable features of the new rules are that no food stuffs will be allowed to be packet in compostable plastics or recycled plastics and imposed ban on use of plastic materials as sachets for packing, storing or selling tobacco products. In addition, enforcement on standards for recycles SUP bags like mandatory to follow Bureau of Indian
Standards (BIS) and to use colors prescribed by the BIS. Thickness should not be less than 40 microns in carry bags, etc. ${ }^{38}$

Despite all these efforts, still India is ranked in 12th position in mismanaging plastic waste management, and this poor outcome in India was due to weak implementation of SUP ban, partly because of irresponsible individual behavior and poor waste management systems. ${ }^{39}$

Tanzania banned single-use plastic in 2005; an initial ban was made in Zanzibar and later extended to the rest of the country for single-use plastic bags. Legislation even extended on imposing ban to the tourist visiting was passed. According to the latest UN environment report, ban is found to be effective in curbing singleuse plastic but has led to increase in air pollution as $40 \%$ of SUP were burned as a plastic waste management. ${ }^{40}$

First in 2007, Kenya imposed a ban on SUP bags less than $30 \mu \mathrm{m}$, and a levy was imposed on SUP bags more than $30 \mu \mathrm{m} 25$; not much of difference was noticed after the ban and levy on plastic bags. ${ }^{34,41}$ El-Habr and Hutchinson in their study reported that the majority of marine littering of SUP was contributed by Kenya; even the animals were affected by SUP as study done by Lange et al. reported that SUP bags found in the stomach of slaughtered livestock. ${ }^{42,43}$

All those alarming situations made Kenya in 2017 to impose toughest ban so far which include 4 years jail or a $\$ 40,000$ fine. It took 10 years and three attempts to finally impose the toughest ban even at the cost of 60,000 jobs lost and facing 176 manufacturers to shut down as Kenya was a major exporter of SUP bags to the region, and 8 months after the ban was introduced, Kenya has drastically reduced SUP waste and the ban was found to be success. ${ }^{44}$ The mayor of North America and Municipal Council unanimously approved By-Law 462 and formulated a legislation to ban SUP shopping in 2007, and the ban was enforced in only two municipalities and Leaf Rapids, Canada, and Manitoba were the first towns in North America to ban plastic bags, but later the government tended to opt for more effective and voluntary stewardship strategies which focused on reusable bags and individual responsibility. As these policies recognize that SUP bags are not the only major component of littering, these bags were a necessity to manage household waste and analyzed that the ban will not be able to eliminate SUP bags from the waste system rather focused toward eliminating plastic kitchen catchers, as they contain up to $76 \%$ more plastic and paper which is 5-7 times heavier, thereby increasing the waste system overall and producing more environmental impact. The initiative was taken to switch people's attitude toward reusable bags and to reduce the number of SUP bags by carrying their own bags and found to be effective. ${ }^{45,46}$

In China, legislation was passed by The General Office of the State Council in December 31, 2008 to ban shops, sales outlets, and supermarkets from providing free SUP bags that are less than $25 \mu \mathrm{m}$ thick and for bags more than $25 \mu \mathrm{m}$, levy was implemented with the exemption in places where these SUP bags need to be used for hygiene issues, viz., storage and handling of fresh food. But adherence to the ban was lacking. More than $80 \%$ retail stores continued to provide SUP bags free of charge but still China managed to reduce SUP bags by $66 \%$ initially. ${ }^{47}$

However, in the long run, the ban was not found to be not effective because of continuous production of SUP plastic bag illegally and lack of an effective measure to control and regulate the quantity of consumers. The other reasons behind the failure of the ban were lack of understanding about the ban among people and lack of self-discipline practices among manufacturers. ${ }^{48}$

In 2011, Wales was the first country among the other countries in UK to pass a Legislation to compact SUP pollution by charging 
a levy on plastic bags; the money raised from the levy on plastic bags were used to improve the environment, and levy on SUP was found to be effective in reducing the SUP. Reports released by Welsh Government in 2012 suggested 96\% reduction in SUP after the levy; further study done by Poortinga et al. on the attitude and behavioral impact of people toward the levy found a positive behavioral spillover effect toward not using SUP because the support for the carrier bag charge was already high before its introduction. ${ }^{49,50}$

In 2015, European Union imposed a legal act (Directive 94/62/ EC was amended) on single-use plastic bags with the main objective of reducing the amount of single-use plastic carrier bag consumed thereby limiting the environmental damage. The ban has been found successful in reducing SUP waste generated and production; the reason behind is the extension of the law to the producers to clean up litter and various initiatives like installing free clean drinking water fountains. $^{51}$
In 2016, Israel introduced a levy on SUP bags, as an effect of the ban more than $70 \%$ of the public supported and a noticeable reduction in SUP was found; the success was partly because bags were charged and the law motivated people to use environmental friendly reusable bags by providing subsidies. ${ }^{52}$

In January of 2019, more than half of India, i.e., 29 states and 7 territories had crafted legislation to ban on SUP and state government officials were ordered to reduce the manufacturing of SUP, further refining an effort which began in 2016 to establish an extended producer responsibility (or EPR guidelines that require manufacturers to pay for the collection and recycling of waste their products). Moreover, local administrations at the city, town, and village levels have been asked to ensure that consumption, distribution, and sale of banned plastic are prevented, ${ }^{53}$ though the impact of the recent initiatives is yet to be evaluated in India.

Summary of countries that have introduced legislation, regulation and bans on SUP are displayed in Table 1.

Table 1: Global plastic bag policy interventions and its impact

\begin{tabular}{|c|c|c|c|c|c|}
\hline S. no. & Country & Year of ban & Policy framework and products ban & Impact of ban & Reason \\
\hline 1 & Bangladesh & 2002 & $\begin{array}{l}\text { The Bangladesh Environment Conservation } \\
\text { Act was revised in 2002. Rule } 6 \text { ka of Clause- } 5 \\
\text { under Section- } 9 \text {, states ban imposed in the } \\
\text { production and uses of thin SUP (polythene } \\
\text { shopping) bag. Penalty and punishment } \\
\text { include imprisonment, fine }\end{array}$ & $\begin{array}{l}\text { Initially reduction in SUP } \\
\text { bags was noticed but later it } \\
\text { increased (from } 5.56 \mathrm{~kg} \text { per } \\
\text { person in } 2005 \text { to } 14.9 \mathrm{~kg} \\
\text { per person in 2014) waste } \\
\text { concern, 2014) }\end{array}$ & $\begin{array}{l}\text { Lack of continuous } \\
\text { enforcement and proper } \\
\text { management for deposited in } \\
\text { recycling centers, or burners } \\
\text { and removal from landfills }\end{array}$ \\
\hline 2 & Ireland & 2002 & $\begin{array}{l}\text { "Bag tax" was passed which imposed a levy } \\
\text { for sale of plastic bags in retail stores and } \\
\text { tax to be paid by consumers also. Levy was } \\
\text { collected only for SUP bags; reuse bags were } \\
\text { exempted from the tax }\end{array}$ & $\begin{array}{l}\text { Overall reduction in SUP } \\
\text { and progressive track record } \\
\text { of less SUP consumed }\end{array}$ & $\begin{array}{l}\text { Tax was imposed from } \\
\text { production of SUP bags to } \\
\text { consumers utilizing it and } \\
\text { increase in tax based on the } \\
\text { increase in consumption }\end{array}$ \\
\hline 3 & India & 2003 & $\begin{array}{l}\text { A legislation was passed in } 2003 \text { to ban } \\
\text { bags less than } 20 \mu \text { m thick later in } 2019, \\
\text { the Ministry of Environment and Forests } \\
\text { had notified another plastic waste rules } \\
\text { for management and handling purpose in } \\
\text { supersession of the earlier rules; partial ban } \\
\text { on SUP items was imposed }\end{array}$ & $\begin{array}{l}\text { India continue to be major } \\
\text { contribution of waste } \\
\text { generated in world despite } \\
\text { of the ban }\end{array}$ & $\begin{array}{l}\text { Irresponsible individual } \\
\text { behavior, poor waste } \\
\text { management systems, and } \\
\text { lack of proper enforcement of } \\
\text { the ban }\end{array}$ \\
\hline 4 & Tanzania & 2005 & $\begin{array}{l}\text { Ban was imposed for bags made up of less } \\
\text { than } 100 \mu \mathrm{m} \text { thickness later banning bags } \\
\text { less than } 30 \mu \mathrm{m}\end{array}$ & $\begin{array}{l}\text { Ban found to be effective in } \\
\text { controlling SUP used and } \\
\text { produced }\end{array}$ & $\begin{array}{l}\text { Effective because of } \\
\text { continuous monitoring }\end{array}$ \\
\hline 5 & Kenya & 2007 & $\begin{array}{l}\text { First in } 2007, \text { Kenya imposed a ban on SUP } \\
\text { bags less than } 30 \mu \mathrm{m} \text { and for SUP bags more } \\
\text { than } 30 \mu \mathrm{m} \text { a levy was imposed. Due to lack } \\
\text { of effectiveness of the ban and levy later in } \\
2017, \text { Kenya enforced world toughest ban } \\
\text { on SUP, which was imprisonment and fine } \\
\text { for using SUP bags less than } 30 \mu \mathrm{m}\end{array}$ & $\begin{array}{l}\text { Effectively reduced } \\
\text { consumption and } \\
\text { production of SUP }\end{array}$ & $\begin{array}{l}\text { Imprisonment, fine, and } \\
\text { continuous monitoring played } \\
\text { a role }\end{array}$ \\
\hline 6 & Canada & $\begin{array}{l}2007 \text { and } \\
2011\end{array}$ & $\begin{array}{l}\text { In } 2007 \text {, a ban was imposed on plastic bags } \\
\text { less than } 30 \mu \mathrm{m} \text {, and a levy was imposed on } \\
\text { bags more than } 30 \mu \mathrm{m} \text { and continue with a } \\
\text { levy for thicker bags }\end{array}$ & $\begin{array}{l}\text { Effective in reducing SUP } \\
\text { and increased reuse bags }\end{array}$ & $\begin{array}{l}\text { Peoples attitude toward } \\
\text { curbing plastic pollution help } \\
\text { to reduce SUP }\end{array}$ \\
\hline 7 & China & 2008 & $\begin{array}{l}\text { Legislation was passed by The General } \\
\text { Office of the State Council to impose ban in } \\
\text { shops, sales outlets and supermarkets from } \\
\text { providing free SUP bags that are less than } \\
25 \mu \text { thick and for bags more than } 25 \mu \mathrm{m} \text {; } \\
\text { levy was implemented with the exemption } \\
\text { in places where these SUP bags need to be } \\
\text { used for hygiene issues, i.e., storage and } \\
\text { handling of fresh food }\end{array}$ & $\begin{array}{l}\text { Initially reduced in } \\
\text { consumption; later increase } \\
\text { in use of SUP were noticed }\end{array}$ & $\begin{array}{l}\text { Lack of monitoring and } \\
\text { illegal production were the } \\
\text { reasons the SUP bags are still } \\
\text { prevailing in China }\end{array}$ \\
\hline
\end{tabular}




\begin{tabular}{|c|c|c|c|c|c|}
\hline S. no. & Country & Year of ban & Policy framework and products ban & Impact of ban & Reason \\
\hline 8 & Wales & 2011 & Legislation to charge a levy on plastic bags & $\begin{array}{l}96 \% \text { reduction in SUP after } \\
\text { the levy }\end{array}$ & $\begin{array}{l}\text { The attitude and behavioral } \\
\text { impact of people toward } \\
\text { the levy found a positive } \\
\text { behavioral spillover effect } \\
\text { toward not using SUP }\end{array}$ \\
\hline 9 & $\begin{array}{l}\text { European } \\
\text { Union }\end{array}$ & 2015 & $\begin{array}{l}\text { Imposed a legal act (directive } 94 / 62 / \text { EC was } \\
\text { amended) on single-use plastic bags }\end{array}$ & $\begin{array}{l}\text { The ban has been found } \\
\text { successful in reducing } \\
\text { SUP waste generated and } \\
\text { production }\end{array}$ & $\begin{array}{l}\text { The extension of the law to } \\
\text { the producers to clean up litter } \\
\text { and various initiatives like } \\
\text { installing free clean drinking } \\
\text { water fondants }\end{array}$ \\
\hline 10 & Israel & 2016 & Introduce a levy on SUP bags & $\begin{array}{l}\text { As an effect of the ban, } \\
\text { more than } 70 \% \text { of the public } \\
\text { supported and noticeable } \\
\text { reduction in SUP }\end{array}$ & $\begin{array}{l}\text { Partly because bags were } \\
\text { charged and the law } \\
\text { motivated people to use } \\
\text { environmental friendly reuse } \\
\text { bags }\end{array}$ \\
\hline
\end{tabular}

\section{Conclusion}

Reasonably charging of plastic bags, imposing high levy on SUP from starting point of production, encouraging innovate measures, tough enforcement, and personal behavior have shown impact in reducing SUP whereas lack of continuous vigilance, self-regulation by industries, and illegal SUP production had led to failure to create impact by various bans and levy. Hence, this article emphasizes that tougher enforcement, vigilance, and self-regulation along with motivations of the public may help to curb SUP pollution.

\section{References}

1. Plastic, Online Etymology Dictionary. Available from: https://www. etymonline.com/search?q=plastic. [Last accessed on 22nd May 2019].

2. Patents for inventions. UK Patent office. p. 255; 1857. Available from: http://www.nationalarchives.gov.uk/help-with-your-research/researchguides/patents-of-invention/. [Last accessed on 22nd May 2019].

3. Nicholson JL, Leighton GR. "Plastics Come of Age". Harper's Magazine 1942; p. 306.

4. United Nations Environment Programme. Single-Use Plastics: A Roadmap for Sustainability; 2018. Available from: https://wedocs. unep.org/bitstream/handle/20.500.11822/25496/singleUsePlastic sustainability.pdf?sequence $=1$ \&isAllowed $=y$ [ Last accessed on 22nd May 2019].

5. GESAMP. Sources, Fate and Effects of Microplastics in the Marine Environment (Part 2); 2016. Available from: http://www.gesamp.org/ publications/microplastics-in-the-marine-environment-part-2. [Last accessed on 22nd May 2019].

6. Barboza LG, Gimenez BC. Microplastics in the marine environment: current trends and future perspectives. Mar Pollut Bull 2015; 97(1-2):5-12. DOI: 10.1016/j.marpolbul.2015.06.008.

7. Zylstra ER. Accumulation of wind-dispersed trash in desert environments. J Arid Environ 2013;89:13-15. DOI: 10.1016/j.jaridenv. 2012.10.004.

8. Barnes DK. Biodiversity: invasions by marine life on plastic debris. Nature 2002;416(6883):808. DOI: 10.1038/416808a.

9. Geyer R, Jambeck JR, Law KL. Production, use, and fate of all plastics ever made. Sci Adv 2017;3(7):e1700782.

10. Annual Report. Implementation of plastic waste management rules,2017-18. Available from: http://cpcb.nic.in/uploads/ plasticwaste/Annual_Report_2017-18_PWM.pdf. [Last accessed on 22nd May 2019].

11. Raqshan T, Tamil Nadu tops in plastic consumption no recycling model in place. Available from: https://www.dtnext.in/ News/TamilNadu/2018/01/25004328/1059588/Tamil-Nadu-tops- in-plastic-consumption-no-recycling-.vpf. [Last accessed on 22nd May 2019].

12. Drzyzga O, Prieto A. Plastic waste management, a matter for the 'community'. Microb Biotechnol 2019;12(1):66. DOI: 10.1111/17517915.13328.

13. North EJ, Halden RU. Plastics and environmental health: the road ahead. Rev Environ Health 2013;28(1):1-8. DOI: 10.1515/reveh-2012-0030.

14. Talsness CE, Andrade AJ, Kuriyama SN, Taylor JA, VomSaal FS. Components of plastic: experimental studies in animals and relevance for human health. Philos Trans R Soc B 2009;364(1526):2079-2096. DOI: 10.1098/rstb.2008.0281.

15. Swan SH, Main KM, Liu F, Stewart SL, Kruse RL, Calafat AM, et al. Decrease in anogenital distance among male infants with prenatal phthalate exposure. Environ Health Perspect 2005;113(8):1056-1061. DOI: 10.1289/ehp.8100.

16. Swan SH. Environmental phthalate exposure in relation to reproductive outcomes and other health endpoints in humans. Environ Res 2008;108(2):177-184. DOI: 10.1016/j.envres.2008.08.007.

17. Lang IA, Galloway TS, Scarlett A, Henley WE, Depledge M, Wallace $R B$, et al. Association of urinary bisphenol A concentration with medical disorders and laboratory abnormalities in adults. JAMA 2008;300(11):1303-1310. DOI: 10.1001/jama.300.11.1303.

18. Adibi JJ, Perera FP, Jedrychowski W, Camann DE, Barr D, Jacek R, et al. Prenatal exposures to phthalates among women in New York City and Krakow, Poland. Environ Health Perspect 2003;111(14):1719-1722. DOI: 10.1289/ehp.6235.

19. Rudel RA, Camann DE, Spengler JD, Korn LR, Brody JG. Phthalates, alkylphenols, pesticides, polybrominateddiphenyl ethers, and other endocrine-disrupting compounds in indoor air and dust. Environ Sci Technol 2003;37(20):4543-4553.

20. Stahlhut RW, Welshons WV, Swan SH. Bisphenol A data in NHANES suggest longer than expected half-life, substantial nonfood exposure, or both. Environ Health Perspect 2009;117(5):784-789. DOI: 10.1289/ehp.0800376.

21. Calafat AM, Weuve J, Ye X, Jia LT, Hu H, Ringer S, et al. Exposure to bisphenol $A$ and other phenols in neonatal intensive care unit premature infants. Environ Health Perspect 2008;117(4):639-644. DOI: 10.1289/ehp.0800265.

22. Thompson RC, Moore CJ, VomSaal FS, Swan SH. Plastics, the environment and human health: current consensus and future trends. Philos Trans R Soc B 2009;364(1526):2153-2166. DOI: 10.1098/ rstb.2009.0053.

23. Vegter AC, Barletta M, Beck C, Borrero J, Burton H, Campbell ML, et al. Global research priorities to mitigate plastic pollution impacts on marine wildlife. Endanger Species Res 2014;25(3):225-247. DOI: 10.3354/esr00623. 
24. Mee A, Rideout BA, Hamber JA, Todd JN, Austin G, Clark M, et al. Junk ingestion and nestling mortality in a reintroduced population of california condors gymnogypscalifornianus. Bird Conserv Int 2007;17(2):119-130. DOI: 10.1017/S095927090700069X.

25. Moore CJ, Lattin GL, Zellers AF. Working our way upstream: a snapshot of land based contributions of plastic and other trash to coastal waters and beaches of Southern California. In Proceedings of the Plastic Debris Rivers to Sea Conference. Long Beach, CA: Algalita Marine Research Foundation; 2005.

26. Brown J, Macfadyen G. Ghost fishing in European waters: Impacts and management responses. Mar Policy 2007;31(4):488-504. DOI: 10.1016/j.marpol.2006.10.007.

27. Gregory MR. Environmental implications of plastic debris in marine settings-entanglement, ingestion, smothering, hangers-on, hitchhiking and alien invasions. Philos Trans R Soc B 2009;364(1526): 2013-2025. DOI: 10.1098/rstb.2008.0265.

28. Van Franeker JA, Heubeck M, Fairclough K, Turner DM, Grantham M, Stienen EW, et al. 'Save the North Sea' Fulmar Study 2002-2004: a regional pilot project for the Fulmar-Litter-EcoQO in the OSPAR area. Alterra; 2005.

29. Zubris KA, Richards BK. Synthetic fibers as an indicator of land application of sludge. Environ Pollut 2005;138(2):201-211. DOI: 10.1016/j.envpol.2005.04.013.

30. Brinton WF. Characterization of man-made foreignmatter and its presence in multiple size fractions from mixed waste composting. Compost Sci Utilizat 2005;13(4):274-280. DOI: 10.1080/1065657X.2005.10702251.

31. Thompson R, Moore C, Andrady A, Gregory M, Takada H, Weisberg S. New directions in plastic debris. Science 2005;310(5751):1117. DOI: 10.1126/science.310.5751.1117b.

32. Chiba S, Saito H, Fletcher R, Yogi T, Kayo M, Miyagi S, et al. Human footprint in the abyss: 30 year records of deep-sea plastic debris. Mar Policy 2018;96:204-212. DOI: 10.1016/j.marpol.2018.03.022.

33. Derraik JG. The pollution of the marine environment by plastic debris: a review. Mar Pollut Bull 2002;44(9):842-852. DOI: 10.1016/ S0025-326X(02)00220-5.

34. United Nations Environment Programme. Selection design and implementation of economic instruments in the solid waste management system in Kenya. The case of plastic bags. UNEP Publications; 2005.

35. Convery F, McDonnell S, Ferreira S. The most popular tax in Europe? Lessons from the Irish plastic bags levy. Environ Resour Econ 2007;38(1):1-1. DOI: 10.1007/s10640-006-9059-2.

36. Hasson R, Leiman A, Visser M. The economics of plastic bag legislation in South Africa. S Afr J Econ 2007;75(1):66-83. DOI: 10.1111/j.18136982.2007.00101.x.

37. Dikgang J, Leiman A, Visser M. Elasticity of demand, price and time: lessons from South Africa's plastic-bag levy. Appl Econ 2012;44(26):3339-3342. DOI: 10.1080/00036846.2011.572859.

38. Natarajan SJ, Manufacture and Usage of Plastic Goods: Press Information Bureau, Government of India, Ministry of Environment,
Forest and Climate Change; 2011. Available from: http://pib.nic.in/ newsite/PrintRelease.aspx?relid=74888. [Last accessed on 22nd May 2019].

39. Jambeck JR, Geyer R, Wilcox C, Siegler TR, Perryman M, Andrady $A$, et al. Plastic waste inputs from land into the ocean. Science 2015;347(6223):768-771. DOI: 10.1126/science.1260352.

40. Pflanz M. Tanzania to ban all plastic bags. The Daily Telegraph 2006.

41. Xanthos D, Walker TR. International policies to reduce plastic marine pollution from single-use plastics (plastic bags and microbeads): a review. Mar Pollut Bull 2017;118(1-2):17-26. DOI: 10.1016/ j.marpolbul.2017.02.048.

42. El-Habr HN, Hutchinson M. Efforts of regional and international organisations in reducing levels of pollution in the Gulf. In: Protecting the Gulf's marine ecosystems from pollution 2008. pp. 93-106.

43. Lange NC, Inganga F, Busienei W, Nguru P, Kiema J, Wahungu G. The prevalence of plastic bag waste in the rumen of slaughtered livestock at three abattoirs in Nairobi Metropolis, Kenya and implications on livestock health. Prevalence 2018;240(1051):991.

44. West CP, Schneider EN, McCrea KM, Grunbeck NB, Determining the Feasibility of a Plastic Reduction Certification Program. 2019.

45. Walker TR, Pettipas S, Bernier M, Xanthos D, Day A. Canada's dirty dozen: a Canadian policy framework to mitigate plastic marine pollution. The ZONE, Fall Issue. Coastal Zone Canada Association 2016. pp. 9-12.

46. Pettipas S, Bernier M, Walker TR. A Canadian policy framework to mitigate plastic marine pollution. Mar Policy 2016;68:117-122. DOI: 10.1016/j.marpol.2016.02.025.

47. Block B, China reports 66-percent drop in plastic bag use; 2013. Available from: http://www.worldwatch.org/node/6167. [Last accessed on 22nd May 2019].

48. Zhu Q. An appraisal and analysis of the law of "Plastic-Bag Ban". Energy Procedia 2011;5:2516-2521. DOI: 10.1016/j.egypro.2011.03.432.

49. Poortinga $W$, Whitmarsh $L$, Suffolk $C$. The introduction of a singleuse carrier bag charge in Wales: Attitude change and behavioural spillover effects. J Environ Psychol 2013;36:240-247. DOI: 10.1016/ j.jenvp.2013.09.001.

50. Schnurr RE, Alboiu V, Chaudhary M, Corbett RA, Quanz ME, Sankar $\mathrm{K}$, et al. Reducing marine pollution from single-use plastics (SUPs): a review. Mar Pollut Bull 2018;137:157-171. DOI: 10.1016/ j.marpolbul.2018.10.001.

51. Kasidoni M, Moustakas K, Malamis D. The existing situation and challenges regarding the use of plastic carrier bags in Europe. Waste Manag Res 2015;33(5):419-428. DOI: 10.1177/0734242X15577858.

52. Ayalon O, Goldrath T, Rosenthal G, Grossman M. Reduction of plastic carrier bag use: An analysis of alternatives in Israel. Waste Manag 2009;29(7):2025-2032. DOI: 10.1016/j.wasman.2009.02.016.

53. Sampathkumar Y, Plastic bans spread in India. Winners and losers aren't who you'd expect; 2019. Available from https://www. nationalgeographic.com/environment/2019/02/india-single-useplastic-bans-maharashtra-tamil-nadu/. [Last accessed on 22nd May 2019]. 